\title{
Ukuran Tubuh Ayam Lokal Silangan IPB D-1 Generasi Kelima Umur 2 Sampai 12 Minggu
}

\author{
Body Size of Local Chicken Crossing IPB D-1 Fifth-Generation from Age 2 until 12 Weeks \\ M. Lukmanudin ${ }^{1}$, C. Sumantri ${ }^{2}$, \& S. Darwati ${ }^{2}$ \\ ${ }^{1}$ Ilmu Produksi dan Teknologi Peternakan, Fakultas Peternakan, IPB \\ ${ }^{2}$ Departemen Ilmu Produksi dan Teknologi Peternakan, Fakultas Peternakan, IPB \\ Fakultas Peternakan Institut Pertanian Bogor \\ Jln. Agatis, Kampus IPB Dramaga, Bogor, 16680, Indonesia \\ Email koresponden author: muhammadlukmanudin19@gmail.com
}

\begin{abstract}
Kampung chicken is Indonesian native chickens that has slow growth. One way to increase growth is crossing. Pelung-sentul-kampung-meat type chicken (IPB D-1) is a chicken from crossing between F1 pelung-sentul (PS) male and kampung-meat type chicken strain cobb (KM) female to produce chicken that has fastly growth and big body size. Factors that need to be examined to find out the bone growth and body structure of chicken is the body size. The aim of the research was to asses body size chicken IPB D-1 generation G4 crosing results with interse at age 2 until 12 weeks. The number of chickens used 33 males and 38 females. The Variables measured every 2 weeks were body weight, shank length, shank circumference, tibia length, femur length, back length, chest circumference, chest width, chest depth, and chest length. Research data were analyzed descriptive. IPB D-1 chicken G5 have a coefficient of diversity $5 \%$ to $15 \%$ on each variable observed. The fifth generation of IPB D-1 chicken (G5) have a variation body size. Chest length is the best variable to predict the body weight.
\end{abstract}

\section{Keywords: crosses, diversity coefficient, IPB D-1 chicken, the body's size}

\section{PENDAHULUAN}

Ayam lokal memiliki potensi untuk dikembangkan di Indonesia. Salah satu rumpun ayam lokal yang mudah dikenali dan banyak dikembangkan masyarakat Indonesia adalah ayam kampung. Ayam kampung didefinisikan sebagai ayam yang tidak mempunyai ciri spesifik yang khas, dengan kata lain memiliki genotipe dan fenotipe yang masih beragam (Sartika 2016). Keunggulan ayam kampung mempunyai daging dengan rasa dan tekstur yang khas, tahan terhadap beberapa penyakit. Ayam kampung memiliki pertumbuhan yang lambat, karena belum banyak pengembangan dari segi genetik. Oleh karena itu perlu dilakukan persilangan antara ayam kampung atau lokal guna meningkatkan produktivitas dan pertumbuhan ayam lokal.

Persilangan ayam lokal dilakukan dengan ayam ras pedaging (meat type chicken) karena ayam ras pedaging sudah mengalami perbaikan mutu genetik. Keunggulan ayam ras pedaging yaitu bentuk tubuh besar, pertumbuhan cepat, kulit putih, daging lembut, kulit halus, tulang dada lunak, dan penghasil daging berserat lunak (Yuwanta 2004). Ayam lokal yang disilangkan yaitu ayam pelung, ayam sentul dan ayam kampung. Ayam pelung merupakan ayam lokal khas Cianjur, Jawa Barat yang memiliki potensi sebagai ayam penyanyi dan pedaging (Sulandari et al. 2007). Menurut Nataamijaya (2000), ayam sentul merupakan salah satu dari 32 rumpun ayam lokal yang sudah teridentifikasi di Indonesia dan mempunyai keunggulan sebagai penghasil daging dan telur (dwiguna).

Persilangan ayam pelung, ayam sentul, ayam kampung, dan ayam ras pedaging dilakukan oleh Daulay (2015). Hasil penelitian Darwati et al. (2016) menunjukan bahwa ayam hasil persilangan ayam lokal dengan ayam ras pedaging meningkatkan produktivitas ayam lokal pada bobot badan dan ukuran tubuh. Persilangan ayam lokal antara ayam pelung dengan ayam sentul menghasilkan keturunan ayam PS. Persilangan ayam kampung dengan ras pedaging strain Cobb menghasilkan keturunan ayam KM. Persilangan ayam PS dan KM menghasilkan keturunan ayam IPB D-1.

Ukuran tubuh merupakan faktor yang perlu dikaji untuk mengetahui pertumbuhan tulang dan struktur tubuh ayam. Ukuran tubuh mempunyai hubungan yang nyata dengan bobot badan. Menurut Getachew dalam Musa et al. (2012), ukuran tubuh dapat digunakan untuk mengestimasi bobot badan pada ternak. Metode yang akurat untuk mengestimasi bobot badan sangat diperlukan untuk program 
pemuliaan dan produksi. Ternak dengan ukuran tulang yang lebih besar cenderung tumbuh lebih cepat dan menghasilkan potongan karkas yang lebih besar dibandingkan dengan yang mempunyai ukuran tulang lebih kecil.

Berdasarkan uraian di atas, penelitian ini dilakukan untuk menambah informasi, mengetahui dan mengevaluasi bentuk keseragaman tentang bobot badan dan ukuranukuran tubuh pada ayam IPB D-1 G5. Pengukuran ukuran tubuh pada ayam IPB D-1 sendiri telah dilakukan selama 4 generasi. Penelitian diharapkan dapat digunakan untuk menunjang penelitian lebih lanjut dalam mengembangkan ayam IPB D-1.

\section{MATERI DAN METODE}

\section{Waktu dan Tempat Penelitian}

Penelitian dilaksanakan di Laboratorium Lapangan Pemuliaan dan Genetika Ternak, Fakultas Peternakan, Institut Pertanian Bogor. Penelitian dilakukan pada bulan September 2017 sampai Januari 2018.

\section{Materi}

Materi yang digunakan pada penelitian ini terdiri atas ayam persilangan pelung sentul kampung ras pedaging (IPB D-1) G4. Ayam IPB D-1 G4 disilangkan dengan sesamanya untuk memperoleh keturunanya yaitu DOC (Day Old Chicken) ayam IPB D-1 G5. Jumlah ayam yang digunakan pada penelitian ini adalah 8 ekor jantan dan 18 ekor betina ayam IPB D-1 G4, sedangkan anakannya yaitu ayam IPB D-1 G5 sebanyak 33 ekor jantan dan 38 ekor betina. Materi lain yang digunakan pada penelitian ini adalah pakan komersial untuk ayam pedaging fase starter berbentuk crumble, dedak padi, vitachick, vaksin, sekam sebagai alas kandang, dan air.

\section{Prosedur}

\section{Persilangan}

Penelitian diawali dengan menyilangkan ayam pelung jantan dengan ayam sentul betina menghasilkan DOC PS dan ayam jantan kampung dengan ayam betina ras pedaging menghasilkan DOC KM. Ayam jantan PS disilangkan dengan ayam betina KM menghasilkan ayam IPB D-1. Ayam IPB D-1 disilangkan dengan sesamanya menghasilkan keturunan ayam IPB D-1 G2. Ayam IPB D-1 G2 disilangkan dengan sesamanya menghasilkan IPB D-1 G3. Selanjutnya ayam IPB D-1 G3 disilangkan dengan sesamanya menghasilkan ayam IPB D-1 G4. Hasil persilangan IPB D-1 G4 disilangkan dengan sesamanya dan menghasilkan ayam IPB D-1 G5. Ayam inilah yang dikaji ukuran tubuh dan morfometriknya.

\section{Pengumpulan Telur dan Penetasan}

Telur dihasilkan dari persilangan ayam IPB D-1 G4 dengan sesamanya. Telur dikumpulkan setiap pagi hari. Setelah telur dikumpulkan selama 1 pekan, telur di tetaskan pada mesin tetas. Telur tetas mula-mula dibersihkan dengan alkohol agar terbebas dari bakteri. Setelah dibersihkan, telur disusun di tray dan dimasukan ke mesin tetas. Penetasan dilakukan selama 21 hari setiap periodenya. Pada hari ke 18 dilakukan pemindahan telur dari mesin setter ke mesin hatcher. Setelah 21 hari penetasan maka akan dihasilkan
DOC ayam IPB D-1 G5.

\section{Pemeliharaan}

Kandang DOC dipersiapkan dan dibersihkan terlebih dahulu dengan menggunakan sapu lidi. Setelah kandang dibersihkan, alas kandang diberi sekam secukupnya. Setiap kandang diberi lampu, tempat pakan, dan tempat minum. Ayam IPB D-1 G5 ini dikandangkan secara koloni berdasarkan umurnya. Ayam diberi wing band (penandaan di kaki) agar memudahkan untuk identifikasi. Setelah ayam berumur 4 minggu, ayam dipisahkan antara jantan dan betina. Selanjutnya pemeliharaan ayam dilakukan pada kandang yang terpisah antara jantan dan betina.

\section{Pemberian Pakan dan Minum}

Pakan diberikan sebanyak 2 kali sehari yaitu pagi dan sore hari. Pakan yang diberikan berupa kombinasi pakan komersial dengan dedak padi. Pakan komersial yang diberikan berbentuk crumble. Proporsi pemberian pakan disesuaikan dengan umur ayam. Pemberian 100\% pakan komersial pada DOC sampai minggu ke-3, perbandingan $80 \%$ pakan komersial : 20\% dedak padi sampai minggu ke-4, kemudian 70\% pakan komersial: 30\% dedak padi sampai minggu ke-5, dilanjutkan dengan perbandingan $60 \%$ pakan komersial : 40\% dedak padi sampai minggu ke-12. Pemberian pakan akan bertambah setiap minggunya. Air minum diberikan ad libitum.

\section{Pencegahan Penyakit}

Pencegahan penyakit dilakukan dengan cara menjaga kebersihan kandang dan lingkungan sekitar kandang. Selain itu diberikan vitachick pada DOC sampai umur 2 minggu. Tetra-Chlor dicampurkan dengan air minum dan diberikan pada ayam yang sakit selama 4 hari. Vaksinasi dilakukan pada ayam dengan metode yang berbeda setiap pemberiannya. Vaksinasi pertama dilakukan pada umur 3 hari melalui tetes mata. Setelah itu pada umur 3 minggu dan 3 bulan dengan menyuntikan vaksin ke bagian dada ayam.

\section{Analisis Data}

Data pada penelitian ini dianalisa secara deskriptif dengan menyajikan rataan (x), simpangan baku (sd) dan koefisien keragaman (KK). Analisis data mengacu pada Noor (2010). Rumus rataan, simpangan baku, dan koefisien keragaman sebagai berikut:

$$
\overline{\mathrm{x}}=\frac{\sum \mathrm{xi}}{\mathrm{n}} \quad \mathrm{sd}=\sqrt{\frac{\sum(\mathrm{Xi}-\mathrm{x})^{2}}{\mathrm{n}-1}} \quad \mathrm{KK}=\frac{\mathrm{sd}}{\mathrm{s}} \times 100
$$

Keterangan :

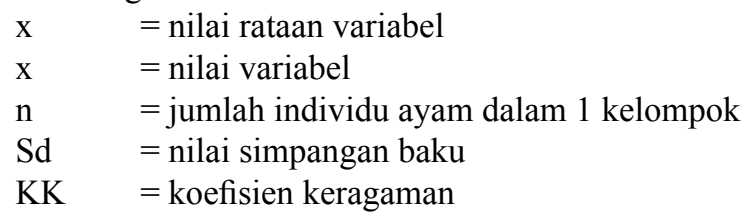

\section{Peubah}

Peubah yang diukur mengacu pada Nishida et al. (1982). Pengukuran peubah yang diamati dilakukan sejak ayam berumur 2 minggu sampai ayam berumur 12 minggu dan diukur setiap 2 minggu sekali. Ukuran tubuh yang diamati seperti disajikan pada Gambar 1. 

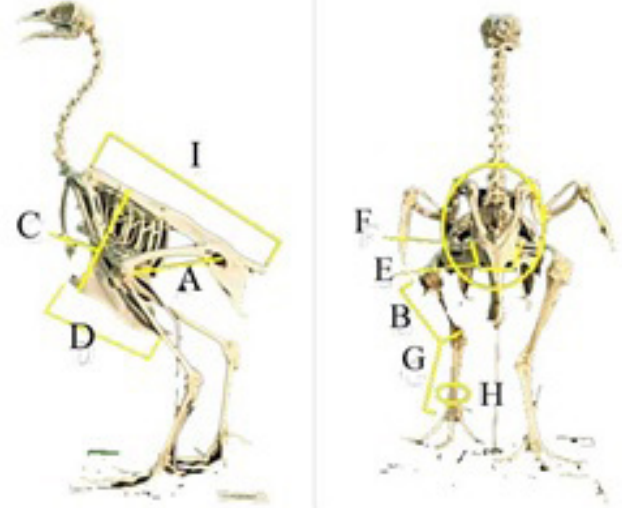

Gambar 1. Bagian-bagian kerangka ayam yang diamati Keterangan: A : panjang femur; B: panjang tibia; C: dalam dada; D : panjang dada; E : lebar dada; F : lingkar dada; G: panjang shank; H : lingkar shank; I : Panjang punggung. Sumber: Waggoner dan Hutchinson (2001).

\section{HASIL DAN PEMBAHASAN}

Tulang Tarsometatarsus (Shank)

Tulang shank yang diukur terdiri dari 2 peubah yaitu panjang shank dan lingkar shank. Hasil rataan pengukuran panjang shank dan lingkar shank ayam IPB D-1 G5 umur 2-12 minggu disajikan pada Tabel 1 dan Tabel 2. Tulang tarsometatarsus (shank) berhubungan dengan kemampuan unggas menopang tubuh. Ayam yang memiliki tulang shank besar akan mampu menopang bobot badan yang besar juga (Mulyono dan Pangestu 1996). Tulang shank dibungkus oleh epidermis dan pigment.

Hasil penelitian rataan pertumbuhan panjang shank ayam IPB D-1 G5 pada umur 12 minggu relatif lebih kecil dibandingkan dengan generasi ke-2 dan generasi ke-3. Rataan panjang shank ayam IPB D-1 G2 hasil penelitian Wiguna (2015) untuk jantan 105,68 mm dan betina 89.91 $\mathrm{mm}$, sedangkan rataan panjang shank ayam IPB D-1 generasi ke-3 berturut-turut 93,07 $\mathrm{mm}$ dan 82,20 mm (Putri 2017). Rataan lingkar shank ayam IPB D-1 G5 pada umur 12 minggu relatif lebih tinggi dibandingkan generasi ke-3 hasil

Tabel 1. Rataan panjang shank ayam IPB D-1 G5 umur 2 sampai 12 minggu

\begin{tabular}{lcc}
\hline \multirow{2}{*}{$\begin{array}{l}\text { Umur } \\
\text { (minggu) }\end{array}$} & \multicolumn{2}{c}{ Rataan $+\mathrm{sb}(\mathrm{KK})$ Panjang Shank } \\
\cline { 2 - 3 } & \multicolumn{2}{c}{ Mantan } \\
\multicolumn{2}{c}{ Metina } \\
\hline & $27,21 \pm 2,45(13 ; 8,99)$ & $27,17 \pm 1,19(15 ; 4,38)$ \\
4 & $45,56 \pm 4,07(30 ; 8,94)$ & $44,29 \pm 4,83(30 ; 10,90)$ \\
6 & $54,24 \pm 3,98(30 ; 7,35)$ & $53,97 \pm 4,82(30 ; 8,94)$ \\
8 & $61,86 \pm 4,28(30 ; 6,92)$ & $58,02 \pm 4,61(30 ; 7,94)$ \\
10 & $68,89 \pm 3,98(30 ; 5,78)$ & $64,36 \pm 3,85(30 ; 5,98)$ \\
12 & $73,55 \pm 3,67(20 ; 4,99)$ & $68,61 \pm 4,79(30 ; 6,98)$ \\
\hline
\end{tabular}

Keterangan: sb: simpangan baku; KK : koefisien keragaman
Tabel 2. Rataan lingkar shank ayam IPB D-1 G5 umur 2 sampai 12 minggu

\begin{tabular}{|c|c|c|}
\hline \multirow{2}{*}{$\begin{array}{l}\text { Umur } \\
\text { (minggu) }\end{array}$} & \multicolumn{2}{|c|}{ Rataan +sb (KK) Lingkar Shank } \\
\hline & Jantan & Betina \\
\hline & \multicolumn{2}{|c|}{$\mathrm{Mm}$} \\
\hline 2 & $1,98 \pm 0,30(20 ; 15,28)$ & $1,90 \pm 0,21(20 ; 11,11)$ \\
\hline 4 & $2,62 \pm 0,19(28 ; 7,50)$ & $2,60 \pm 0,21(30 ; 8,24)$ \\
\hline 6 & $3,09 \pm 0,22(28 ; 7,04)$ & $3,06 \pm 0,25(30 ; 8,20)$ \\
\hline 8 & $3,50 \pm 0,26(28 ; 7,63)$ & $3,30 \pm 0,28(29 ; 8,57)$ \\
\hline 10 & $3,82 \pm 0,31(28 ; 7,98)$ & $3,70 \pm 0,25(27 ; 6,64)$ \\
\hline 12 & $4,13 \pm 0,32(18 ; 7,74)$ & $3,80 \pm 0,23(23 ; 6,11)$ \\
\hline
\end{tabular}

Keterangan: sb: simpangan baku; KK : koefisien keragaman

penelitian Putri (2017). Rataan lingkar shank ayam IPB D-1 generasi generasi ke-3 umur 12 minggu untuk jantan 4,06 $\mathrm{cm}$ dan betina $3,82 \mathrm{~cm}$ (Putri 2017). Hal ini diduga karena postur tubuh ayam IPB D-1 generasi ke-2 dan generasi ke-3 lebih besar dibandingkan generasi ke-5.

Rataan panjang shank dan lingkar shank ayam IPB D-1 generasi ke-5 jantan lebih panjang dibandingkan ayam betina. Menurut Mufti (2003) selain umur ternak, laju pertumbuhan tulang antara ayam jantan dan betina berbeda. Pertumbuhan Tulang shank masih berlanjut hingga ayam berumur 12 minggu. Kemungkinan pertumbuhan masih akan terus tumbuh pada minggu-minggu berikutnya. Hal ini sesuai dengan pendapat Jull (1979) yang menyatakan bahwa rataan pertumbuhan tulang mempunyai tendensi mengalami kenaikan pada umur 4 minggu sampai 12 minggu, kemudian mulai mengalami penurunan laju pertumbuhan pada umur 12-20 minggu.

\section{Tulang Paha}

Rataan hasil pengukuran panjang femur dan panjang tibia ayam IPB D-1 G5 umur 2-12 minggu disajikan dalam Tabel 3 dan 4 . Tulang paha terdiri dari 2 bagian, yaitu tulang paha atas (femur) dan tulang paha bawah (tibia). Paha merupakan organ eksterior tubuh yang berfungsi menopang tubuh dan menjaga keseimbangan. Paha atas (tulang femur) memiliki ukuran yang lebih pendek dari paha bawah (tulang tibia) (Widodo 2012).

Hasil penelitian rataan pertumbuhan panjang femur ayam IPB D-1 G5 pada umur 12 minggu relatif lebih kecil dibandingkan dengan generasi ke-2 dan generasi ke-3. Rataan panjang femur ayam IPB D-1 G2 hasil penelitian Wiguna (2015) untuk jantan 103,91 $\mathrm{mm}$ dan betina 88,39 mm, sedangkan rataan panjang femur ayam IPB D-1 generasi ke-3 berturut-turut 93,07 mm dan 88,27 mm (Putri 2017). Rataan panjang femur ayam IPB D-1 G5 pada umur 12 minggu relatif lebih tinggi dibandingkan penelitian yang dilakukan oleh Suryaman (2001) bahwa panjang femur ayam kampung umur 12 minggu sebesar 89,65 mm untuk jantan dan 85,34 mm untuk betina. Hal ini terjadi karena adanya komposisi genetik ras pedaging dari ayam IPB D-1 sehingga memiliki postur yang lebih besar.

Bagian tulang paha lainnya yaitu tulang tibia. Rataan pertumbuhan panjang tulang tibia generasi ke-5 relatif lebih tinggi daripada generasi ke-3 yaitu sebesar 110,12 mm 
Tabel 3. Rataan panjang tibia ayam IPB D-1 G5 umur 2 sampai 12 minggu

\begin{tabular}{|c|c|c|}
\hline \multirow{2}{*}{$\begin{array}{l}\text { Umur } \\
\text { (minggu) }\end{array}$} & \multicolumn{2}{|c|}{ Rataan $+\mathrm{sb}(\mathrm{KK})$ Panjang Tibia } \\
\hline & Jantan & Betina \\
\hline & \multicolumn{2}{|c|}{$\mathrm{mm}$} \\
\hline 2 & $50,95 \pm 3,93(30 ; 7,71)$ & $49,92 \pm 4,56(32 ; 9,14)$ \\
\hline 4 & $74,91 \pm 4,73(30 ; 6,32)$ & $73,77 \pm 5,55(32 ; 7,53)$ \\
\hline 6 & $90,17 \pm 6,33(30 ; 7,02)$ & $86,71 \pm 8,37(32 ; 9,65)$ \\
\hline 8 & $104,87 \pm 7,31(30 ; 6,97)$ & $102,10 \pm 6,54(32 ; 6,41)$ \\
\hline 10 & $117,54 \pm 7,38(30 ; 6,28)$ & $114,49 \pm 6,11(32 ; 5,34)$ \\
\hline 12 & $126,98 \pm 5,38(20 ; 4,24)$ & $121,08 \pm 7,56(32 ; 6,24)$ \\
\hline
\end{tabular}

Keterangan: sb : simpangan baku; KK : koefisien keragaman

Tabel 4. Rataan panjang femur ayam IPB D-1 G5 umur 2 sampai 12 minggu

\begin{tabular}{|c|c|c|}
\hline \multirow{2}{*}{$\begin{array}{l}\text { Umur } \\
\text { (minggu) }\end{array}$} & \multicolumn{2}{|c|}{ Rataan +sb (KK) Panjang Femur } \\
\hline & Jantan & Betina \\
\hline & \multicolumn{2}{|c|}{$\mathrm{mm}$} \\
\hline 2 & $38,98 \pm 3,34(30 ; 8,58)$ & $38,68 \pm 4,05(30 ; 10,46)$ \\
\hline 4 & $55,08 \pm 3,22(30 ; 5,84)$ & $54,09 \pm 3,73(30 ; 6,90)$ \\
\hline 6 & $65,95 \pm 5,04(30 ; 7,65)$ & $63,75 \pm 6,06(30 ; 8,45)$ \\
\hline 8 & $75,46 \pm 4,89(30 ; 6,48)$ & $73,59 \pm 4,57(30 ; 6,21)$ \\
\hline 10 & $85,52 \pm 7,26(30 ; 8,49)$ & $81,43 \pm 4,99(30 ; 6,13)$ \\
\hline 12 & $90,82 \pm 5,52(20 ; 6,07)$ & $88,10 \pm 5,74(30 ; 6,52)$ \\
\hline
\end{tabular}

Keterangan: sb: simpangan baku; KK : koefisien keragaman

untuk jantan dan 102,71 mm (Putri 2017). Panjang tibia ayam IPB D-1 G5 ini lebih besar bila dibandingkan dengan hasil penelitian ayam kampung Suryaman (2001). Rataan panjang tibia ayam kampung hasil penelitian Suryaman (2001) sebesar 126,85 mm untuk jantan dan 119,22 mm untuk betina. Hal ini menunjukan bahwa ayam IPB D-1 G5 memiliki performa panjang tibia yang lebih baik dibandingkan ayam kampung.

Tulang tibia memiliki ukuran yang lebih panjang dari tulang femur. Pertumbuhan pada tulang paha berkaitan erat dengan pertumbuhan konformasi otot pada ayam. Bagian paha ayam memiliki perdagingan yang paling banyak setelah bagian dada (Laela 1991). Menurut Sartika (2000) bahwa bobot badan berkorelasi positif dengan ukuran tulang tibia. Bobot badan yang tinggi mengindikasikan bahwa pertumbuhannya baik karena nutrien dalam ransum mampu digunakan secara maksimal baik untuk pertumbuhan tulang, daging maupun lemak (Bangun 2013). Konformasi tulang yang besar menunjukan bahwa pertumbuhan daging baik karena konformasi tulang yang dibentuk sebagai tempat melekatnya otot juga baik.

\section{Tulang Dada}

Pertumbuhan rataan dalam dada pada umur 12 minggu relatif lebih kecil dibandingkan dari penelitian ayam IPB D-1 G3 Putri (2017). Hasil penelitian Putri (2017) rataan dalam dada pada ayam IPB D-1 G3 umur 12 minggu pada jantan sebesar 99,09 $\mathrm{mm}$ dan pada betina $93,58 \mathrm{~mm}$.
Rataan Lebar dada ayam IPB D-1 G5 umur 12 minggu relatif lebih besar dibandingkan dengan ayam kampung penelitian Kurnia (2011). Hasil penelitian Kurnia (2011) rataan lebar dada pada ayam kampung jantan umur 12 minggu sebesar $44,41 \mathrm{~mm}$ dan pada betina $42,71 \mathrm{~mm}$. Rataan dalam dada, lebar dada, panjang dada dan lingkar dada ayam IPB D-1 G5 jantan dan betina dari umur 2 minggu sampai 12 minggu disajikan pada Tabel 5, 6, 7, dan 8 .

Rataan panjang dada ayam IPB D-1 generasi ke-5 relatif lebih kecil dibandingkan generasi ke-5. Panjang dada ayam IPB D-1 generasi ke-3 sebesar 96,24 mm untuk jantan dan 91,27 mm untuk betina (Putri 2017). Hasil penelitian ini relatif lebih besar dibandingkan dari penelitian ayam kampung Suryaman (2001). Suryaman (2001) melaporkan bahwa rataan panjang dada pada ayam kampung umur 12 minggu yaitu $88,12 \mathrm{~mm}$ pada jantan dan $83,64 \mathrm{~mm}$ pada betina. Lingkar dada IPB D-1 generasi ke-5 lebih kecil dibandingkan IPB D-1 generasi ke-3 tetapi relatif lebih besar dari ayam kampung. Ayam IPB D-1 generasi ke-3 memiliki lingkar dada sebesar $303,10 \mathrm{~mm}$ untuk jantan dan 281,10 mm untuk betina umur 12 minggu (Putri 2017). Hasil penelitian Kurnia (2001) rataan lingkar dada ayam kampung umur 12 minggu yaitu $21,23 \mathrm{~cm}$ pada jantan dan $20,39 \mathrm{~cm}$ pada betina.

Rataan tulang dada ayam IPB D-1 G5 jantan lebih besar dibandingkan dengan betina. Perbedaan pertumbuhan ini dapat disebabkan adanya faktor internal (hormon) dan

Tabel 5. Rataan dalam dada ayam IPB D-1 G5 umur 2 sampai 12 minggu

\begin{tabular}{lcc}
\hline $\begin{array}{l}\text { Umur } \\
\text { (minggu) }\end{array}$ & \multicolumn{2}{c}{ Rataan $+\mathrm{sb}(\mathrm{KK})$ Dalam Dada } \\
Jantan & Betina \\
\hline \multicolumn{3}{c}{$\mathrm{mm}$} \\
2 & $43,72 \pm 2,79(40 ; 6,38)$ & $43,58 \pm 3,48(30 ; 7,98)$ \\
4 & $60,32 \pm 4,67(40 ; 7,74)$ & $60,29 \pm 3,73(30 ; 6,86)$ \\
6 & $72,64 \pm 4,90(40 ; 6,75)$ & $70,14 \pm 5,44(30 ; 7,75)$ \\
8 & $82,68 \pm 5,93(29 ; 7,18)$ & $78,33 \pm 4,06(30 ; 5,18)$ \\
10 & $90,75 \pm 5,52(29 ; 6,08)$ & $85,34 \pm 5,18(30 ; 6,07)$ \\
12 & $96,17 \pm 6,68(20 ; 6,95)$ & $91,21 \pm 6,14(30 ; 6,73)$ \\
\hline
\end{tabular}

Keterangan: sb : simpangan baku; KK : koefisien keragaman

Tabel 6. Rataan lebar dada ayam IPB D-1 G5 umur 2 sampai 12 minggu

\begin{tabular}{lcc}
\hline \multirow{2}{*}{$\begin{array}{l}\text { Umur } \\
\text { (minggu) }\end{array}$} & \multicolumn{2}{c}{ Rataan + sb (KK) Lebar Dada } \\
\cline { 2 - 3 } & \multicolumn{2}{c}{ Mm } \\
\hline \multicolumn{2}{c}{ Betina } \\
\hline & $28,63 \pm 2,84(30 ; 9,93)$ & $28,50 \pm 3,02(30 ; 10,59)$ \\
6 & $37,99 \pm 3,04(30: 8,01)$ & $37,34 \pm 2,84(30 ; 7,59)$ \\
8 & $43,18 \pm 2,85(30 ; 6,61)$ & $41,51 \pm 2,69(30 ; 8,48)$ \\
10 & $46,77 \pm 3,26(29 ; 6,97)$ & $45,14 \pm 2,58(29 ; 5,72)$ \\
12 & $51,12 \pm 4,02(27 ; 7,87)$ & $48,88 \pm 3,22(29 ; 6,59)$ \\
\hline & $54,76 \pm 4,37(20 ; 7,98)$ & $53,06 \pm 3,40(29 ; 6,41)$ \\
\hline
\end{tabular}

Keterangan: sb: simpangan baku; KK : koefisien keragaman 
faktor eksternal (pakan). Hormon yang mempengaruhi pertumbuhan ini adalah testosteron. Menurut Rudiono (2007) testosteron merupakan hormon steroid dari ternak jantan yang mempunyai kemampuan anabolisme protein. Hasil kerja hormon testosteron pada ternak jantan adalah kemampuan pertumbuhan yang cepat. Hormon testosteron yang rendah akan meningkatkan pelebaran dari epiphysis tulang dan membantu hormon pertumbuhan, sedangkan hormon estrogen berpengaruh sebagai penghambat pertumbuhan (Herren 2000). Faktor eksternal pada ayam IPB D-1 jantan dan betina dapat disebabkan oleh dedak padi yang berkualitas kurang baik.

Tabel 7. Rataan panjang dada ayam IPB D-1 umur 2 sampai 12 minggu

\begin{tabular}{lcc}
\hline \multirow{2}{*}{$\begin{array}{l}\text { Umur } \\
\text { (minggu) }\end{array}$} & \multicolumn{2}{c}{ Rataan + sb (KK) Panjang Dada } \\
\cline { 2 - 3 } & \multicolumn{2}{c}{ Jantan } \\
\hline \multicolumn{2}{c}{ Betina } \\
2 & $39,24 \pm 4,03(32 ; 10,27)$ & $38,50 \pm 3,31(30 ; 8,60)$ \\
4 & $55,94 \pm 4,44(32 ; 7,95)$ & $55,00 \pm 4,17(30 ; 7,59)$ \\
6 & $65,50 \pm 4,41(32 ; 6,73)$ & $65,20 \pm 4,50(30 ; 7,01)$ \\
8 & $73,15 \pm 6,20(30 ; 8,47)$ & $72,96 \pm 5,36(30 ; 7,35)$ \\
10 & $85,12 \pm 7,18(28 ; 8,44)$ & $80,62 \pm 5,14(30 ; 6,38)$ \\
12 & $93,69 \pm 7,82(20 ; 8,35)$ & $89,98 \pm 8,74(30 ; 9,72)$ \\
\hline
\end{tabular}

Keterangan: sb: simpangan baku; KK : koefisien keragaman

Tabel 8. Rataan lingkar dada ayam IPB D-1 G5 umur 2 sampai 12 minggu

\begin{tabular}{lcc}
\hline \multirow{2}{*}{$\begin{array}{l}\text { Umur } \\
(\text { minggu })\end{array}$} & \multicolumn{2}{c}{ Rataan $+\mathrm{sb}(\mathrm{KK})$ Lingkar Dada } \\
\cline { 2 - 3 } & \multicolumn{2}{c}{$\mathrm{cm}$} \\
& \multicolumn{2}{c}{ Betina } \\
\hline & $11,67 \pm 0,77(30 ; 6,61)$ & $11,61 \pm 0,95(30 ; 8,21)$ \\
6 & $16,27 \pm 1,36(30 ; 8,36)$ & $16,22 \pm 1,04(30 ; 6,41)$ \\
8 & $19,67 \pm 1,37(30 ; 6,95)$ & $18,58 \pm 1,28(30 ; 6,93)$ \\
10 & $21,89 \pm 1,55(30 ; 7,07)$ & $20,98 \pm 1,36(30 ; 6,50)$ \\
12 & $24,45 \pm 1,83(28 ; 7,50)$ & $23,17 \pm 1,53(30 ; 6,60)$ \\
\hline
\end{tabular}

Keterangan: sb : simpangan baku; KK : koefisien keragaman

Dada merupakan tempat deposisi daging yang lebih banyak jika dibandingkan dengan organ lain sehingga dengan mengetahui laju pertumbuhan tulang dada dapat dijadikan sebagai indikator besar atau kurusnya ternak tersebut (Widodo 2012). Laju pertumbuhan tulang dipengaruhi oleh konsumsi protein karena protein bermanfaat untuk pertumbuhan ternak tersebut. Protein berperan dalam pertumbuhan jaringan pada tubuh dalam hal ini dada. Hal ini sesuai dengan pendapat Mahfudz et al. (2009) asam amino merupakan pembentuk jaringan tubuh, termasuk jaringan otot (daging) yang akhirnya menghasilkan karkas. Hasil penelitian menunjukan konformasi tulang dada yang relatif lebih besar dibanding ayam kampung, maka dapat diduga bahwa ayam IPB D-1 G5 memiliki bobot badan yang relatif lebih besar juga dibandingkan dengan ayam kampung.

\section{Panjang Punggung}

Panjang punggung antara jantan dan betina tidak jauh berbeda setiap 2 minggu. Hal tersebut berarti bahwa fungsi tulang punggung pada jantan dan betina ayam IPB D-1 tidak berbeda. Panjang punggung ayam IPB D-1 generasi ke-5 umur 12 minggu lebih rendah dibandingkan generasi ke-2 dan ke-3. Panjang punggung ayam IPB D-1 generasi ke-2 sebesar 28,05 $\mathrm{cm}$ dan 25,60 cm (Wiguna 2016), sedangkan IPB D-1 generasi ke-3 sebesar 20,90 cm dan 18,15 cm (Putri 2017). Hasil penelitian Suryaman (2001) melaporkan bahwa rataan panjang punggung ayam kampung umur 12 minggu yaitu $13,67 \mathrm{~cm}$ pada jantan dan $13,07 \mathrm{~cm}$ pada betina sedangkan menurut kurnia (2011) panjang punggung ayam kampung jantan sebesar 13,20 $\mathrm{cm}$ dan betina sebesar $12,86 \mathrm{~cm}$. Hal ini berarti bahwa performa panjang punggung ayam IPB D-1 G5 lebih panjang dibandingkan ayam kampung. Tulang punggung dan pinggul terdiri atas beberapa tulang yang menyatu. Konformasi punggung yang kaku ini mendukung kuat bagi melekatnya otot sayap dan pergerakan sayap pada waktu terbang (Suprijatna 2005). Rataan panjang punggung ayam IPB D-1 jantan dan betina generasi ke-5 disajikan pada Tabel 9.

Tabel 9. Rataan panjang punggung ayam IPB D-1 G5 umur 2-12 minggu

\begin{tabular}{|c|c|c|}
\hline \multirow{2}{*}{$\begin{array}{l}\text { Umur } \\
\text { (minggu) }\end{array}$} & \multicolumn{2}{|c|}{ Rataan +sb (KK) Panjang Punggung } \\
\hline & Jantan & Betina \\
\hline & \multicolumn{2}{|c|}{$\mathrm{cm}$} \\
\hline 2 & $6,39 \pm 0,48(30 ; 7,48)$ & $6,36 \pm 0,54(30 ; 8,47)$ \\
\hline 4 & $9,53 \pm 1,11(30 ; 11,37)$ & $9,51 \pm 0,86(30 ; 9,08)$ \\
\hline 6 & $11,90 \pm 0,96(30 ; 8,09)$ & $11,73 \pm 0,79(30 ; 6,73)$ \\
\hline 8 & $15,16 \pm 1,55(30 ; 10,21)$ & $13,37 \pm 1,33 \quad(30 ; 9,92)$ \\
\hline 10 & $17,14 \pm 1,81(28 ; 10,55)$ & $16,90 \pm 1,78(30 ; 10,53)$ \\
\hline 12 & $18,37 \pm 1,78(20 ; 9,69)$ & $17,61 \pm 1,54(26 ; 8,75)$ \\
\hline
\end{tabular}

Keterangan: sb: simpangan baku; KK : koefisien keragaman

\section{Bobot Badan}

Tulang merupakan tempat perlekatan dari otot sehingga dapat diduga jika kerangka tubuh sama besar maka bobot badan juga akan sama beratnya. Mansjoer (1985) menambahkan bahwa terdapat beberapa sifat yang berhubungan dengan produktivitas unggas yaitu bobot badan dan mempunyai hubungan yang nyata dengan ukuran tubuhnya. Hasil rataan pengukuran bobot badan ayam IPB D-1 generasi ke-5 umur 2-12 minggu disajikan pada Tabel 10.

Pertambahan bobot badan dikorelasikan dengan beberapa ukuran tubuh dari masing-masing jantan dan betina ayam IPB D-1 G5. Hasil perhitungan ayam jantan dan betina IPB D-1 secara berurutan adalah 0,952 dan 0,946 (panjang shank), 0,974 (panjang tibia), 0,974 dan 0,982 (panjang femur), 0,986 dan 0,985 (panjang dada), 0,964 dan 0,970 (lebar dada), 0,968 dan 0,969 (lingkar dada), 0,961 dan 0,971 (dalam dada), dan 0,975 dan 0,983 (panjang punggung). Dari perhitungan data tersebut, maka peubah yang paling baik untuk menduga pertumbuhan atau bobot badan pada jantan maupun betina ayam IPB D-1 G5 adalah panjang dada. 
Tabel 10. Rataan bobot badan ayam IPB D-1 umur 2-12 minggu

\begin{tabular}{lcc}
\hline $\begin{array}{l}\text { Umur } \\
\text { (minggu) }\end{array}$ & \multicolumn{2}{c}{ Rataan + sb (KK) Bobot Badan } \\
\cline { 2 - 3 } & & Betina \\
\hline 2 & $121,27 \pm 24,20(33 ; 19,95)$ & g ekor $^{-1}$ \\
4 & $289,43 \pm 50,23(30 ; 13,78)$ & $112,76 \pm 25,66(38 ; 22,75)$ \\
6 & $475,39 \pm 85,74(29 ; 18,03)$ & $257,72 \pm 54,71(37 ; 21,22)$ \\
8 & $670,25 \pm 100,53(28 ; 14,99)$ & $431,52 \pm 78,50(34 ; 18,19)$ \\
10 & $894,59 \pm 152,65(27 ; 17,06)$ & $624,71 \pm 101,50(28 ; 16,24)$ \\
12 & $1181,16 \pm 203,36(25 ; 17,21)$ & $813,29 \pm 122,31(27 ; 15,03)$ \\
\hline
\end{tabular}

Keterangan: sb: simpangan baku; KK : koefisien keragaman

\section{Koefisien Keragaman Ukuran Tubuh}

Koefisien keragaman tertinggi ukuran tubuh ayam IPB D-1 generasi ke-5 untuk jantan dan betina berturutturut terdapat pada peubah lingkar shank sebesar 6,97\%$15,28 \%$ dan panjang punggung sebesar 8,46\%-11,68\%. Hal ini menunjukkan bahwa lingkar shank dan panjang punggung ayam IPB D-1 generasi ke-5 lebih beragam dan harus dilakukan seleksi. Seleksi merupakan suatu tindakan untuk membiarkan ternak-ternak tertentu bereproduksi, sedangkan ternak lainnya tidak diberikan kesempatan bereproduksi (Noor 2010). Seleksi ini dilakukan agar keturunan ayam IPB D-1 generasi ke-5 memiliki ukuran tubuh yang seragam.

Koefisien keragaman terendah ukuran tubuh ayam IPB D-1 generasi ke-5 untuk jantan dan betina berturutturut terdapat pada peubah panjang tibia sebesar 4,24\%$7,71 \%$ dan dalam dada sebesar 5,19\%-7,98\%. Keragaman pada panjang tibia dan dalam dada termasuk dalam kategori sedang. Menurut Kurnianto (2010), kategori keragaman dapat dibedakan menjadi 3, yaitu keragaman kecil $(\mathrm{KK} \leq 5 \%)$, keragaman sedang $(5 \%<\mathrm{KK}<15 \%)$, dan keragaman tinggi $(\mathrm{KK} \geq 15 \%)$. Hal ini berarti peubah tibia dan dalam dada tidak perlu diseleksi kembali karena sudah mendekati seragam.

Keragaman pada ternak bersumber dari keragaman genetik, keragaman lingkungan dan keragaman interaksi genetik lingkungan. Keragaman genetik bisa disebabkan oleh gen aditif, gen dominan dan gen epistasis sedangkan keragaman lingkungan disebabkan oleh faktor iklim, cuaca, makanan, penyakit serta sistem manajemen (Noor 2010). Keragaman pada ayam IPB D-1 generasi ke-5 ini diduga karena pengaruh lingkungan yaitu faktor iklim, cuaca, dedak yang digunakan, dan penyakit.

Secara umum ayam IPB D-1 G5 lebih beragam dibandingkan generasi ke-2 dan ke-3. Menurut Wiguna (2016), koefisien keragaman ayam IPB D-1 generasi ke-2 berkisar antara $0,03 \%$ sampai 4,62\% dan generasi ke-3 berkisar antara 3,12\% sampai 11,8\% (Putri 2017). Ayam IPB D-1 G5 termasuk dalam kategori keragaman sedang. Keberagaman ayam IPB D-1 G5 ini memungkinkan untuk dilakukan seleksi sebelum dikembangkan lebih lanjut. Penyeleksian ini dilakukan agar ayam yang dijadikan tetua memiliki produksi maupun reproduksi yang lebih unggul.

\section{Pertumbuhan Kerangka}

Pertumbuhan ukuran ayam IPB D-1 G3 dan G5 umur 2-12 minggu disajikan pada Gambar 2-10. Simamora (2014) menyatakan bahwa pertumbuhan adalah suatu proses pertambahan ukuran baik melalui pertambahan ukuran tulang, pertambahan keperluan protein, air dan mineral di dalam tubuh. Pertumbuhan pada tulang sangat penting, karena tulang berfungsi sebagai tempat bertautnya otot, melindungi organ-organ yang lunak, dan organ reproduksi (Herren 2000).

Laju pertumbuhan ukuran tubuh ayam IPB D-1 G5 pada umur 2-4 minggu lebih cepat, tetapi mulai menurun pada umur 6-12 minggu. Jull (1979) menyatakan bahwa rataan laju pertumbuhan tulang mempunyai tendensi mengalami kenaikan pada umur 4-12 minggu dan akan

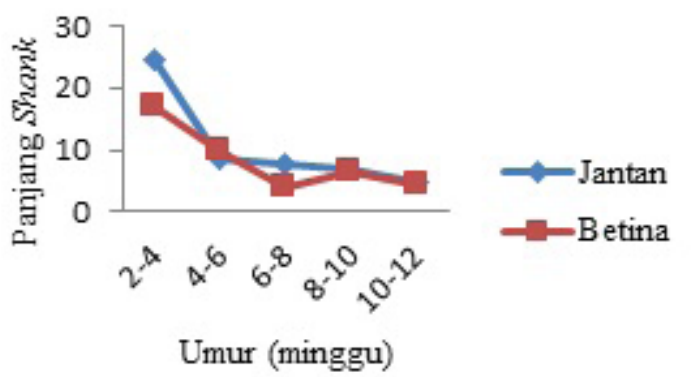

Gambar 2. Grafik pertumbuhan ukuran panjang shank ayam PSKM G5

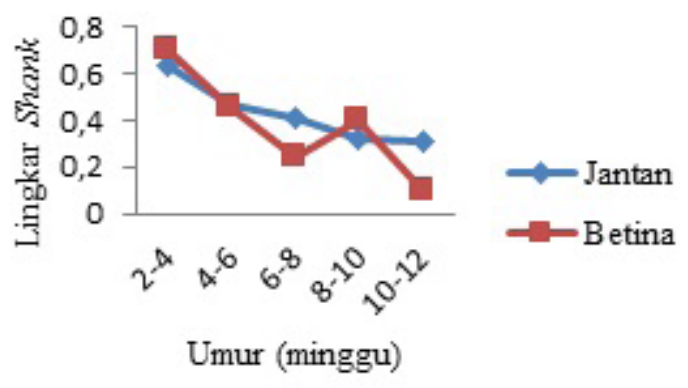

Gambar 3. Grafik pertumbuhan ukuran lingkar shank ayam PSKM G5 


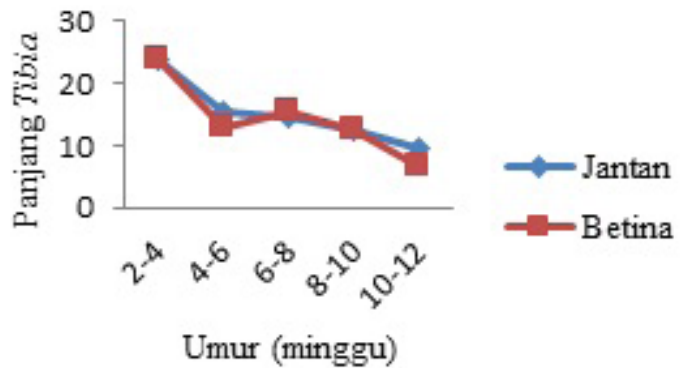

Gambar 4. Grafik pertumbuhan ukuran panjang tibia ayam PSKM G5

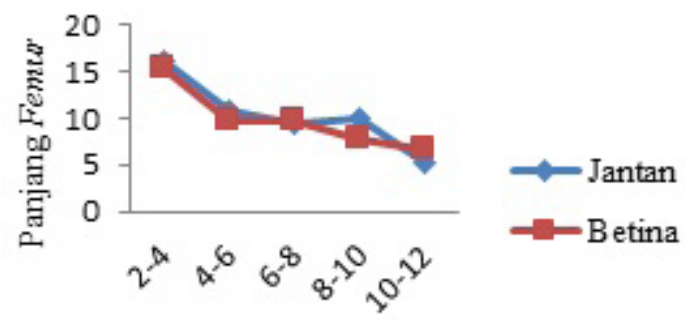

Umur (minggu)

Gambar 5. Grafik pertumbuhan ukuran panjang femur ayam PSKM G5

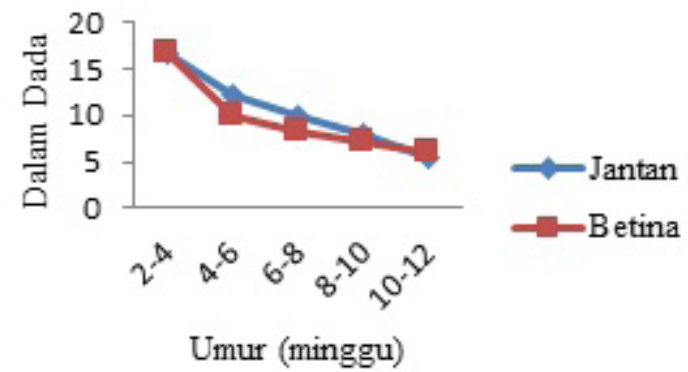

Gambar 6. Grafik pertumbuhan ukuran dalam dada ayam PSKM G5

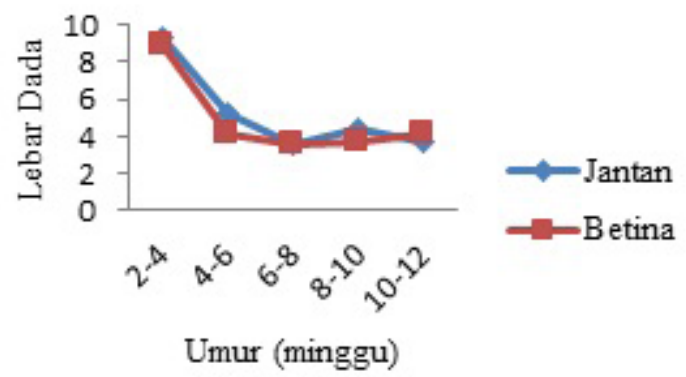

Gambar 7. Grafik pertumbuhan ukuran lebar dada ayam PSKM G5

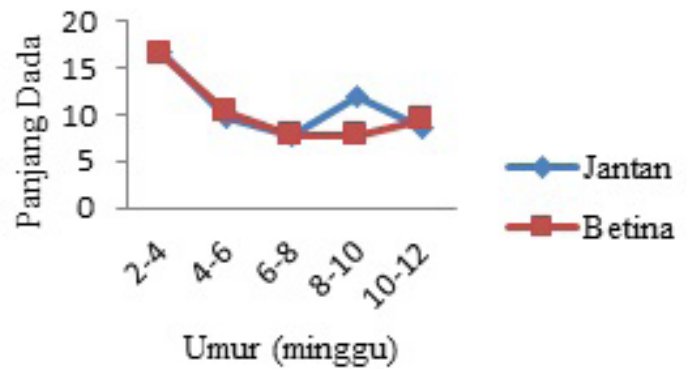

Gambar 8. Grafik pertumbuhan ukuran panjang dada ayam PSKM G5

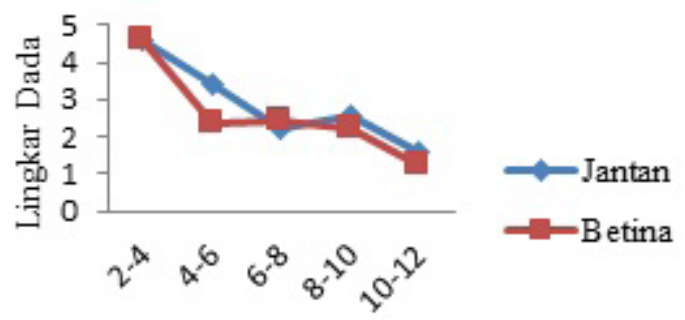

Umur (minggu)

Gambar 9. Grafik pertumbuhan ukuran lingkar dada ayam PSKM G5

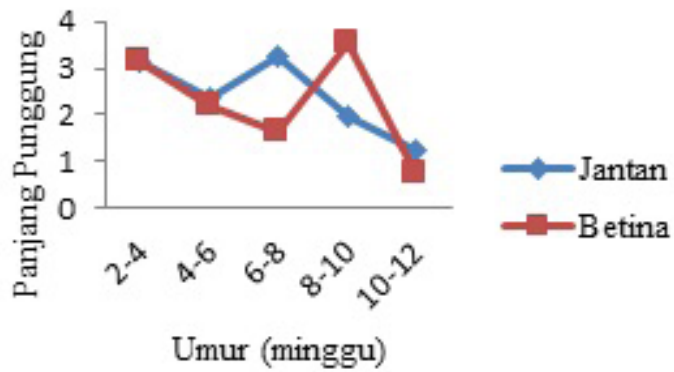

Gambar 10. Grafik pertumbuhan ukuran panjang punggung ayam PSKM G5

menurun pada umur 12-20 minggu. Hal ini terjadi karena periode ini merupakan fase tumbuh dipercepat dan pada saat tersebut terjadi perbanyakan (hyperplasia) dan pembesaran (hypertrophy) dari sel-sel tubuh (Asnawi 1997). Fase pertumbuhan ini harus diimbangi dengan pemberian pakan yang berkualitas agar pertumbuhan optimal. Pertumbuhan optimal membutuhkan pakan dengan kandungan nutrisi yang tinggi (Haitook 2006). Menurut Wijayanti (2011) laju pertumbuhan dipengaruhi oleh genetik, jenis kelamin, manajemen kandang, kualitas, dan kuantitas pakan yang dikonsumsi.

Laju pertumbuhan ayam IPB D-1 G5 umur 2-12 minggu cenderung menurun pada peubah panjang dada, dalam dada, panjang tibia, panjang femur. Ukuran tubuh lainnya (panjang shank, lingkar shank, panjang tibia, lebar dada, panjang dada, lingkar dada, dan panjang punggung) 
terjadi laju pertumbuhan yang fluktuatif setiap 2 minggu. Hal ini menunjukan bahwa laju pertumbuhan tulang mendekati optimum dan kemungkinan akan berhenti. Pada saat pertumbuhan tulang maksimal, maka pertumbuhan otot akan tumbuh dengan cepat.

\section{KESIMPULAN}

Ayam persilangan IPB D-1 generasi ke-5 (G5) umur 2-12 minggu memilikiukuran tubuh dan koefisien keragaman yang sedang. Ayam IPB D-1 generasi ke-5 memiliki ukuran tubuh yang beragam sehingga seleksi masih sangat efektik untuk dilakukan dalam meningkatkan mutu genetik ternak hasil persilangan. Panjang dada merupakan peubah terbaik untuk menduga bobot badan jantan dan betina ayam IPB D-1 G5. Laju pertumbuhan ayam IPB D-1 G5 cenderung menurun pada peubah panjang dada, dalam dada, panjang tibia dan panjang femur.

\section{DAFTAR PUSTAKA}

Asnawi.1997. Kinerja pertumbuhan dan fisiologis ayam kampung dan hasil persilangan dengan ayam ras. Tesis. Bogor (ID): Institut pertanian Bogor.

Bangun, G. D. D., L. D. Mahfudz, \& D. Sunarti. 2013. Effect of Seaweed Gracilaria verrucosa Meal Utilization in Broiler's Diet on Weight and Size of Tibia and Tarsometatarsus. Animal Agriculture Journal. 2(1):489-496.

Daulay, M. A. C. 2015. Ukuran tubuh hasil silangan ayam kampung ras pedaging dengan ayam pelung sentul umur 2-10 minggu. Skripsi. Bogor (ID): Institut Pertanian Bogor.

FAO (Food and Agriculture Organization of The United Nations). 2012. Phenotypic Characterization of Animal Genetic Resources. FAO Animal Production and Health Guidelines No. 11. Roma (IT): FAO.

Haitook, T. 2006. Study on chicken meat production for small-scale farmer in Northeast Thailand. Disertasi. Jerman [DE]: Kassel Univ Pr.

Herren, R. 2000. The Science of Animal Agriculture. Ed ke-2. Delmar, New York.

Kurnia, Y. 2011. Morfometrik ayam sentul, kampung dan kedu pada fase pertumbuhan dari umur 1-12 minggu. Skripsi. Bogor (ID): Institut Pertanian Bogor.

Kurnianto, E. 2010. Ilmu Pemuliaan Ternak. Universitas Diponegoro, Semarang.

Laela, S. 1991. Produksi karkas, giblet dan lemak abdominal dua galur ayam broiler. Karya ilmiah. Bogor (ID): Fakultas Peternakan IPB.

Mahfudz, L. D., F. L. Maulana, U. Atmomarsono, \& T. A. Sarjana. 2009. Karkas dan lemak abdominal ayam broiler yang diberi ampas bir dalam ransum. Seminar Nasional Kebangkitan Peternakan Semarang. Semarang (ID): Universitas Diponegoro.

Mansjoer, S. S. 1985. Pengkajian sifat produksi ayam kampung persilangannya dengan ayam Rhode Island Red Disertasi. Bogor (ID): IPB.

Mufti, R. 2003. Studi ukuran dan bentuk tubuh ayam
Kampung, ayam Pelung dan persilangannya. Skripsi. Bogor (ID): Fakultas Peternakan IPB.

Mulyono, R. H., R. B. Pangestu. 1996. Analisis statistik ukuran-ukuran tubuh dan karakter genetik ayam kampung, pelung dan kedu. Dalam Seminar Hasil Penelitian. Bogor (ID): Fakultas Peternakan IPB.

Musa, A. M., N. Z. Idam, \& K. M. Elamin. 2012. Regression analysis of linier body measurements on live weight in Sudanese Shugor sheep. Online J.anim. Feed Res. 2(1): 27-29.

Nataamijaya, A. G. 2000. The native chicken of Indonesia. Bulletin Plasma Nutfah. 6(1):1-6.

Nishida, T., K. Nozawa, Y. Hayashi, Y. Hashiguchi, \& S. S. Mansjoer. 1982. Body measurement and analysis of external genetic characters of Indonesian native fowl. The Origin and Phylogeny of Indonesian Native Livestock. The Research Group of Overseas Scientific Survey. Hal : 73-83.

Noor, R. R. 2010. Genetika Ternak. Penebar Swadaya, Jakarta.

Putri, A. Y. 2017. Morfometri ayam persilangan IPB D-1 generasi ketiga umur 2 sampai 12 minggu. Skripsi. Bogor (ID): Institut Pertanian Bogor.

Rudiono, D. 2007. Pengaruh hormon testosteron dan umur terhadap karakteristik karkas kambing kacang betina. JITV. 1: 34-41.

Sartika, T., S. Iskandar, \& B. Tiesnamurti. 2016. Sumberdaya Genetik ayam Lokal Indonesia dan Prospek Pengembangannya. IAARD Pr, Jakarta.

Simamora, D. 2014. Ukuran tubuh ayam F1 persilangan ayam kampung dengan ayam ras pedaging umur 0-12 minggu. Skripsi. Bogor (ID): Institut Pertanian Bogor.

Sulandari, S., M. S. A. Zein, S. Paryanti, T. Sartika, M. Astuti, T. Widjastuti, E. Sudjana, S. Darana, I. Setiawan, D. Garnida, \& et al. 2007. Sumberdaya genetik ayam lokal Indonesia. Keanekaragaman Sumberdaya Hayati Ayam Lokal Indonesia: Manfaat dan Potensi. Jakarta (ID): Pusat Penelitian Biologi Lembaga Ilmu Pengetahuan Indonesia.

Suryaman, A. 2001. Perbandingan morfometrik ayam kampung, ayam pelung dan ayam keturunan pertama (F1) persilangan pelung kampung jantan dan betina. Skripsi. Bogor (ID): Institut Pertanian Bogor.

Waggoner, B., J. B. Hutchinson. 2001. Aves:More on Morphology. http://www.ucmp.berkely.edu/diapsids/. html. [diunduh 2017 November 5].

Widodo, A., W. Sarengat, \& E. Suprijatna. 2012. Pengaruh lama periode pemberian pakan terhadap laju pertumbuhan pada beberapa bagian tubuh ayam pelung umur 1-11 minggu. Animal Agriculture Journal. $1(2): 120-125$.

Wiguna, K. I. M. 2016. Ukuran tubuh hasil persilangan ayam lokal dengan ras pedaging umur 2 sampai 12 minggu. Skripsi. Bogor (ID): Institut Pertanian Bogor.

Wijayanti, R. P. 2011. Pengaruh suhu kandang yang berbeda terhadap performans ayam pedaging periode starter. Skripsi. Malang (ID): Universitas Brawijaya

Yuwanta, T. 2004. Dasar Ternak Unggas. Kanisius, Yogyakarta. 